\title{
Subtitusi Minyak Ikan Dengan Minyak Jagung Dalam Pakan Terhadap Efisiensi Pakan Dan Pertumbuhan Juvenil Rajungan (Portunus pelagicus) Yang Dipelihara Dalam Sistem Resirkulasi
}

\author{
[Subtitution of Fish Oil with Corn Oil in the Diet on Feed Efficiency and Growth of \\ Swimming Crabs (Portunus pelagicus) Juvenile Maintained in Recirculation System]
}

Friska Pattricya Noya*, Muhammad Idris, Oce Astuti, Agus Kurnia

Program Studi Budidaya Perairan, Fakultas Perikanan dan Ilmu Kelautan Universitas Halu Oleo Jl. H.E.A Mokodompit Kampus Baru Tridharma, Andonohu, Kendari. 93232, Indonesia

*Email :friskapattricyanoya@gmail.com

\begin{abstract}
ABSTRAK
Penelitian ini bertujuan untuk mengetahui pengaruh subtitusi minyak ikan (MI) dengan minyak jagung (MJ) terhadap pertumbuhan dan kelangsungan hidup benih rajungan (P. pelagicus). Tiga jenis pakan dibuat berdasarkan subtitusi MI dengan MJ yang terdiri atas : Pakan A (6\% MI + 0\%MJ), Pakan B (3\% MI + 3\% MJ), dan Pakan C (2\% MI + 4\% MJ). Sebanyak 36 ekor benih rajungan (bobot awal rata-rata : 39,31 $\pm 2.20 \mathrm{~g}$ ) dimasukkan ke dalam 12 akuarium (3 ekor/ akuarium) yang berukuran $60 \times 50 \times 40 \mathrm{~cm}$. Rajungan diberi pakan 2 kali sehari $(17.00$ dan 22.00 WITA) dengan dosis $10 \%$ dari bobot tubuh selama 60 hari pemeliharaan. Hasil Penelitian ini menunjukkan bahwa substitusi MI dengan MJ dalam pakan buatan memberikan pengaruh yang berbeda nyata terhadap konsumsi pakan, rasio konversi pakan, efisiensi pakan, retensi protein, dan retensi lemak.namun tidak memberikan pengaruh yang berbeda nyata terhadap pertumbuhan mutlak rata-rata, laju pertumbuhan spesifik, dan tingkat kelangsungan hidup rajungan. Pertumbuhan mutlak rata-rata yang diperoleh pada penelitian ini berkisar 1,25-2,46 g, laju pertumbuhan spesifik berkisar antara 0,0005-0,00101\%, konsumsi pakan tertinggi diperoleh sebesar $625,68 \mathrm{~g}$, rasio konversi pakan sebesar 187,41 , efisiensi pakan $0,85 \%$, dan tingkat kelangsungan hidup sebesar 75,00-91,67 \%. Penelitian ini menyimpulkan bahwa pemberian 3\% minyak ikan dan 3\% minyak jagung dalam pakan buatan menghasilkan pertumbuhan, efisiensi pakan dan kelangsungan hidup tertinggi juvenil rajungan (P. pelagicus) pada pemeliharaan system resirkulasi.
\end{abstract}

Kata Kunci: Juvenil Rajungan (P. pelagicus), Minyak Ikan, Minyak Jagung, Pertumbuhan, Kelangsungan Hidup

\section{ABSTRACT}

This study aims to determine the effect of substitution of fish oil (FO) with corn oil (CO) on the growth and feed efficiency of swimming crab (P. pelagicus) juvenile. Three experimental diets were prepared based on the substitution of FO with $\mathrm{CO}$ which consisted of: $6 \%$ FO $+0 \%$ CO (Diet A), 3\% FO + 3\% CO (Diet B), and 2\% FO + 4\% CO (Diet C). A total of 36 swimming crab juvenile (mean initial weight: $38.54 \pm 39.91 \mathrm{~g}$ ) were distributed into 12 aquariums ( 3 crabs / aquarium) with size : $60 \times 50 \times 40 \mathrm{~cm}$. The crabs were fed in two times a day $(05.00$ p.m and $10.00 \mathrm{p} . \mathrm{m})$ with dosage of $10 \%$ of total biomass of crabs for 60 days of maintenance. The results of this study indicate that the substitution of FO with CO in artificial feed has a significantly different effect on feed consumption (FC). feed conversion ratio (FCR), feed efficiency (FE), protein retention (PR), and lipid retention (LR). However, it did not have any significantly different on the weight gain, specific growth rate (SGR), and survival rate (SR) of the crabs. The weight gain of crabs that obtained in this study was ranged between 1.25 to $2.46 \mathrm{~g}$ and SGR of the crabs was ranged between $0.0005-0.00101 \%$. The highest of FC was found in the crabs fed with Diet B $(625.68 \mathrm{~g})$. In addition, the highest of FCR, FE, and SR were found in the crabs fed with Diet B with values of $187.41,0.85 \%$, and $91.67 \%$, respectively. This study concluded that supplementation of $3 \%$ fish oil and $3 \%$ corn oil in artificial feed resulted in the optimum growth, feed efficiency and survival rate of juvenile swimming crab (P. pelagicus) that reared in recirculating system.

Keywords: Crab (P. pelagicus) seeds, fish oil, corn oil, growth, survival.

\section{PENDAHULUAN}

Rajungan (Portunus pelagicus) merupakan salah satu komoditas penting perikanan. Rajungan termasuk jenis krustase komersial selain rasa dagingnya yang lezat juga bergizi cukup tinggi yakni protein $65,72 \%$, mineral 7,5\% dan lemak 0,88\% (Soim,1996).
Menurut PPN Karangantu (2014), produksi rajungan ( $P$. pelagicus) di PPN Karangantu dalam tahun 2009-2013 rata-rata sebesar 73,706 ton. Produksi rajungan tertinggi diperoleh pada tahun 2012 sebesar 79,291 ton, dan terendah diperoleh pada tahun 2011 sebesar 63,554 ton. Permintaan akan daging rajungan yang semakin meningkat baik dari pasar lokal 
maupun pasar ekspor, sehingga perlu diimbangi dengan produksi budidaya rajungan yang lebih tinggi (Suharyanto dan Tahe, 2005; Suharyanto et al., 2006). Namun, hingga saat ini seluruh kebutuhan ekspor rajungan masih mengandalkan dari hasil tangkapan alam yang menimbulkan khawatirkan akan mempengaruhi populasi di alam. Penangkapan induk dan benih yang berlebihan dapat mengakibatkan berkurangnya kelimpahan benih rajungan di alam (Mardjono dkk., 2002). Sehingga perlu dilakukan suatu usaha budidaya rajungan.

Salah satu faktor yang menentukan keberhasilan usaha budidaya adalah manajemen pakan. Akan tetapi penggunaan ikan rucah sebagai pakan dalam kegiatan pembesaran rajungan merupakan salah satu kendala karena memiliki beberapa kekurangan, selain karena kualitas (kesegaran) ketersediaan juga menjadi salah satu faktor. Kekurangan lain ikan rucah di samping harga mahal, mudah rusak, cepat busuk juga kontinyuitasnya tidak dapat terjamin. Oleh karena itu, ikan rucah memerlukan penanganan yang tepat dan memadai agar kualitasnya tetap terjaga dengan baik (Suwirya et al., 2005).

Laju pertumbuhan rajungan yang dibudidayakan juga cenderung lambat. Hal tersebut dapat disebabkan oleh berbagai macam faktor salah satunya adalah karena kurangnya nutrisi yang dibutuhkan dalam pakan ikan rucah. Menurut hasil penelitian Suharyanto (2012), rajungan memberikan respon yang sama terhadap pakan ikan rucah dan pakan buatan (pellet), sehingga pakan buatan dapat digunakan untuk budidaya rajungan. Selain itu, pakan buatan dapat diatur komposisi bahan dan dapat disesuaikan dengan kebutuhan nutrisi rajungan. Komposisi bahan pakan harus seimbang antara protein, lemak, karbohidrat, vitamin dan mineral sesuai dengan kebutuhan nutrisi rajungan.

Komposisi bahan pakan harus seimbang antara protein, lemak, karbohidrat, vitamin dan mineral sesuai dengan kebutuhan nutrisi rajungan. Salah satu bahan baku pakan yang berperan penting dan berfungsi sebagai sumber energy terbesar adalah sumber lemak. Minyak ikan merupakan salah satu bahan baku yang diperlukan dalam komposisi pakan buatan sebagai sumber lemak. Menurut Sunarto dan Sabariah (2008) lemak dan minyak merupakan salah satu sumber energi yang paling tinggi dalam pakan ikan. Menurut Kurniasih dkk. (2015), pemanfaatan minyak secara efisien sebagai sumber energi dapat menggantikan energi yang berasal dari protein, sehingga dapat meningkatkan efisiensi pemanfaatan protein. Dosis total minyak hewani dan nabati pada kadar protein yang sama dalam pakan atau disebut juga rasio energi protein $(E / P)$ dapat memberi pengaruh terhadap pertumbuhan. Pemanfaatan protein oleh ikan belum optimal, sehingga diduga protein digunakan sebagai energi. Menurut Nasution (2002), lemak dalam pakan berfungsi sebagai sumber energi dan juga penting sebagai sumber lemak essensial untuk proses pertumbuhan dan pertahanan tubuh. Menurut Maulana dkk. (2014), sumber pakan yang kaya akan asam lemak omega-3 dapat diperoleh dari minyak ikan laut. Minyak ikan merupakan penyuplai utama dalam asam lemak yang memiliki rantai panjang yang tidak jenuh.

Berdasarkan data statistika, pada tahun 2011 diketahui nilai impor Indonesia untuk minyak ikan sebesar 4.666 ton dengan nilai nominal 17.555 juta dolar Amerika. Sedangkan nilai ekspornya sendiri adalah sebesar 183,407 ton atau setara dengan 589,132 juta dolar Amerika (KKP, 2012). Akan tetapi, Minyak ikan menjadi sumber bahan pakan yang mahal, sehingga perlu dicari sumber lemak alternatif dari lemak nabati sebagai bahan pakan dan harganya relatif lebih murah.

Salah satu sumber lemak alternatif yang dapat digunakan untuk bahan baku pakan yaitu minyak jagung. Menurut Alfin dkk. (2017), minyak jagung ini memiliki kandungan asam lemak jenuh (palmitat dan stearat) serta asam lemak tidak jenuh, yaitu oleat (omega 9), linoleat (omega-6), dengan persentase kandungan asam oleat $20 \%-50 \%$, asam linoleat $35 \%-60 \%$, fosfolipid $2 \%$ serta bahan tak tersabunkan 2\% (tokoferol sitosferol dan lilin). Oleh karena itu, minyak jagung dapat berpotensi menjadi sumber lemak alternatif dalam pakan buatan. Minyak jagung telah dimanfaatkan sebagai sumber bahan pada pakan. Minyak jagung dapat digunakan sebagai bahan pakan sumber lemak alternatif pengganti minyak ikan untuk pemeliharaan lobster air laut di karamba jaring apung. Karena memberikan respon yang sama dengan minyak ikan. 
Umumnya pemeliharaan rajungan secara tradisional di karamba. Namun, seiring dengan pemanfaatan ruang laut untuk kegiatan lain seperti pariwisata, transportasi, dan pembangunan jembatan menyebabkan area budidaya rajungan di laut semakin berkurang. Ancaman lain dari kegiatan budidaya di laut adalah polusi laut dan kondisi alam berupa badai ombak besar, sehingga dapat menurunkan produksi dari usaha budidaya rajungan. Diperlukan metode intensifikasi budidaya rajungan menggunakan sistem resirkulasi di dalam ruangan. Sistem pemeliharaan rajungan menggunakan metode resirkulasi menjadi alaternatif untu mengatasi permasalahan diatas. Namun, informasi mengenai metode pemeliharaan rajungan mengunakan sistem resirkulasi masih terbatas.Berdasarkan informas tersebut maka perlu dilakukan penelitian mengenai subtitusi minyak ikan dengan minyak jagung terhadap efisiensi pakan dan pertumbuhan juvenil rajungan pada sistem resirkulasi.

\section{BAHAN DAN METODE}

Perlakuan uji pakan pada benih rajungan ( $P$. pelagicus) dilaksanakan di Laboratorium
Unit Pembenihan dan Produksi, Fakultas Perikanan dan Ilmu Kelautan, Universitas Halu Oleo pada bulan September sampai November 2020.

\section{Hewan Uji}

Hewan uji pada penelitian ini adalah benih rajungan ( $P$. pelagicus) yang diperoleh dari hasil tangkapan alam di Desa Tapulaga, Kecamatan Soropia, Kabupaten Konawe, Provinsi Sulawesi Tenggara dengan bobot ratarata awal 39,31 $\pm 2,20$ gram/ekor, sebelum pelaksanaan penelitian terlebih dahulu hewan uji diadaptasikan selama 1 minggu di dalam wadah pemeliharaan. Selama proses adaptasi, hewan uji diberi pakan komersil.

\section{Pakan Uji}

Pakan uji dibuat dengan persentasi dosis minyak ikan dan minyak jagung adalah perlakuan A yaitu 6\% MI dan $0 \%$ MJ, perlakuan B yaitu 3\% MI dan 3\% MJ, perlakuan C yaitu 2\% MI dan 4\% MJ yang didesain menggunakan Rancangan Acak Lengkap (RAL), terdiri dari 3 perlakuan dan 4 ulangan (Tabel 1).

Tabel 1. Formulasi Pakan Uji pada Setiap Perlakuan.

\begin{tabular}{lccc}
\hline \multirow{2}{*}{ Bahan Baku Pakan } & \multicolumn{3}{c}{ Jumlah Bahan Baku Pakan pada Setiap Perlakuan (\%) } \\
\cline { 2 - 4 } & A & B & C \\
\hline Tepung Ikan Tembang & 25 & 25 & 25 \\
Tepung kepala Udang & 25 & 25 & 25 \\
Tepung Kedelai & 25 & 25 & 25 \\
Tepung Jagung & 5 & 5 & 5 \\
Tepung Dedak Halus & 5 & 5 & 5 \\
Tepung Tapioka & 1 & 1 & 1 \\
Tepung Sagu & 1 & 1 & 1 \\
Tepung Terasi & 5 & 5 & 5 \\
Minyak Ikan & 6 & 3 & 2 \\
Minyak jagung & 0 & 3 & 4 \\
Top Mix & 1 & 1 & 1 \\
\hline Total & 100 & 100 & 100 \\
\hline
\end{tabular}

\section{Analisis Proksimat}

Pakan uji yang telah dibuat kemudian dianalisa proksimat meliputi kadar protein, lemak, serat kasar, kadar abu, kadar air dan bahan ekstrak tanpa nitrogen (BETN). Analisa proksimat pakan dan kualitas air dilaksanakan di Laboratorium Produktivitas dan Lingkungan Perairan FPIK-UHO, Kendari. 


\section{Pemeliharaan Rajungan Uji}

Pemeliharaan benih rajungan dilakukan didalam akuarium dengan ukuran $80 \times 35 \times 45$ $\mathrm{cm}$ sebanyak 12 unit yang diisi dengan air laut sebanyan $80 \%$ dari volume akuarium dan dilengkapi dengan sistem resirkulasi.Hewan uji dipelihara selama 60 hari dengan bobot rata-rata awal $39,31 \pm 2,20 \mathrm{~g}$ dan kepadatan 3 ekor/wadah.Pergantian air dilakukan melalui proses penyiponan. Penyiponan dilakukan setiap hari yaitu pada pagi hari sebelum pemberian pakan. Penyiponan bertujuan agar sisa-sisa pakan maupun sisa feses dapat dikeluarkan sehingga tidak terjadi penumpukan dan pembusukan pada media. Sisa pakan diambil dan dikeringkan untuk penghitungan konsumsi pakan. Selanjutnya dilakukan pemberian pakan sebanyak $10 \%$ dari bobot tubuh dengan frekuensi dua kali sehari yaitu pada jam 17.00 dan pada jam 22.00 Wita.

\section{Variabel yang Diamati}

\section{Pertumbuhan Mutlak Rata-rata}

Pertumbuhan mutlak rata-rata dihitung dengan menggunakan persamaan :

$$
\mathrm{Wm}=\mathrm{Wt}-\mathrm{W} 0
$$

Dengan: $\mathrm{Wm}=$ pertumbuhan mutlak ratarata $(\mathrm{g}) ; \mathrm{Wt}=$ bobot rata-ratarajunganpada akhir penelitian $(\mathrm{g})$; $\mathrm{W} 0=$ bobot rata-rata rajungan pada awal penelitian $(\mathrm{g})$.

\section{Laju Pertumbuhan Spesifik}

Laju Pertumbuhan Spesifik (LPS) dihitung menggunakan persamaan :

$$
\mathrm{SGR}=\frac{\operatorname{Ln} W t-\operatorname{Ln} W 0}{t} \times 100 \%
$$

Dengan : SGR = laju pertumbuhan spesifik $(\%) ; \mathrm{Wt}=$ bobot rata-rata rajungan pada akhir penelitian $(\mathrm{g})$; $\mathrm{W} 0=$ bobot rata-rata rajungan pada awal penelitian $(\mathrm{g}) ; \mathrm{t}=$ lama pemeliharaan (hari).

\section{Konsumsi Pakan}

Konsumsi pakan dihitung menggunakan persamaan :

$$
\mathrm{FC}=\mathrm{F} 1-\mathrm{F} 2
$$

Dengan : $\mathrm{FC}=$ konsumsi pakan $(\mathrm{g}) ; \mathrm{F} 1=$ total pakan yang diberi $(\mathrm{g}) ; \mathrm{F}=$ sisa pakan $(\mathrm{g})$.

\section{Rasio Konversi Pakan}

Rasio konversi pakan dihitung menggunakan persamaan :

$$
\mathrm{FCR}=\frac{\mathrm{F}}{(\mathrm{Wt}+\mathrm{D})-\mathrm{W} 0}
$$

Dengan $: \mathrm{FCR}=$ rasio konversi pakan; $\mathrm{F}=$ total pakan yang dikonsumsi $(\mathrm{g})$; $\mathrm{Wt}=$ bobot individu pada akhir penelitian (g); $\mathrm{W} 0=$ bobot individu pada awal penelitian $(\mathrm{g})$; $\mathrm{D}=$ bobot ikan mati.

\section{Efisiensi Pakan}

Efisiensi pakan benih rajungan dihitung menggunakan persamaan :

$$
\mathrm{EF}=\frac{1}{F C R} \times 100 \%
$$

Dengan : $\mathrm{EF}=$ efisiensi pakan (\%); $\mathrm{FCR}=$ rasio konversi pakan

\section{Tingkat Kelangsungan Hidup}

Tingkat kelangsungan hidup benih rajungan dihitung dengan menggunakan persamaan :

$$
\mathrm{SR}=\frac{\mathrm{Nt}}{\mathrm{N} 0} \times 100 \%
$$

Dengan $: \mathrm{SR}=$ tingkat kelangsungan hidup $(\%) ; \mathrm{Nt}=$ jumlahrajunganpada akhir penelitian (ekor); $\mathrm{N} 0=$ jumlah rajungan pada awal penelitian (ekor).

\section{Kualitas Air}

Selama penelitian berlangsung pengamatan dan pengukuran kualitas air meliputi pengamatan salinitas air, suhu air, $\mathrm{pH}$, Amonia, dan oksigen terlarut. Suhu air diukur setiap hari selama penelitian sedangkan salinitas, $\mathrm{pH}$, oksigen terlarut dan ammonia awal dan akhir penelitian.

\section{Analisis Data}

Keseluruhan data kecuali kualitas air dianalisis dengan menggunakan analisis ragam dengan bantuan program SPSS versi 16.0, jika menunjukkan perbedaan yang nyata maka dilanjutkan dengan uji Duncan. 


\section{HASIL}

\section{Pertumbuhan Mutlak Rata-rata}

Hasil perhitungan pertumbuhan mutlak rata-rata juvenil rajungan $(P$. pelagicus $)$ selama penelitian dari setiap perlakuan disajikan pada Gambar 1.Hasil analisis ragam menunjukkan bahwa perlakuan tidak memeberikan pengaruh yang berbeda nyata terhadap pertumbuhan mutlak rata-rata benih rajungan $(P$. pelagicus $)(\mathrm{P}=0.385>0,05)$.

\section{Laju Pertumbuhan Spesifik}

Hasil perhitungan laju pertumbuhan spesifik benih rajungan ( $P$. pelagicus) selama penelitian dari setiap perlakuan disajikan pada Gambar 2. Hasil analisis ragam menunjukkan bahwa perlakuan tidak memeberikan pengaruh yang berbeda nyata terhadap laju pertumbuhan spesifik benih rajungan $(P$. pelagicus $)(\mathrm{P}=$ $0,882>0,05 ; \mathrm{P}=0,696>0,05 ; \mathrm{P}=0,307>0,05$, berturut-turut pada LPS 20, LPS 40, dan LPS $60)$.

\section{Konsumsi Pakan}

Hasil perhitungan konsumsi pakan juvenil rajungan ( $P$. pelagicus) selama penelitian dari setiap perlakuan disajikan pada Gambar 3. Hasil analisis ragam menunjukkan bahwa perlakuan memeberikan pengaruh yang berbeda nyata terhadap konsumsi pakan benih rajungan $(P$. pelagicus $)(\mathrm{P}=0,041<0,05)$. Hasil uji Duncan menunjukkan bahwa perlakuan B berbeda nyata dengan perlakuan $\mathrm{C}$ tetapi tidak berbeda nyata dengan perlakuan $\mathrm{A}$, sedangkan perlakuan $\mathrm{C}$ berbeda nyata dengan perlakuan $\mathrm{B}$ tetapi tidak berbeda nyata dengan perlakuan A.

\section{Rasio Konversi Pakan}

Hasil perhitungan rasio konversi pakan juvenil rajungan ( $P$. pelagicus) selama penelitian dari setiap perlakuan disajikan pada Gambar 4. Hasil analisis ragam menunjukkan bahwa perlakuan memberikan pengaruh yang berbeda nyata terhadap rasio konversi pakan juvenil rajungan $(P$. pelagicus $)(\mathrm{P}=0,21<0,05)$. Hasil uji Duncan menunjukkan bahwa perlakuan $\mathrm{C}$ berbeda nyata dengan perlakuan A dan B. sedangkan perlakuan B berbeda nyata dengan perlakuan $\mathrm{C}$ tetapi tidak berbeda nyata dengan perlakuan $\mathrm{A}$.

\section{Efisiensi Pakan}

Hasil perhitungan efisiensi pakan juvenil rajungan ( $P$. pelagicus) selama penelitian dari setiap perlakuan disajikan pada Gambar 5. Hasil analisis ragam menunjukkan bahwa perlakuan pakan yng berbeda memberikan pengaruh yang berbeda nyata terhadap efisiensi pakan benih rajungan $(P$. pelagicus) $(\mathrm{P}=014,<0,05)$. Hasil uji Duncan menunjukkan bahwa perlakuan $\mathrm{B}$ berbeda nyata dengan perlakuan $\mathrm{C}$ tetapi tidak berbeda nyata dengan perlakuan A. Sedangkan perlakuan $\mathrm{C}$ berbeda nyata dengan perlakuan A dan B.

\section{Tingkat Kelangsungan Hidup}

Hasil perhitungan tingkat kelangsungan hidup juvenil rajungan $(P$. pelagicus $)$ selama penelitian dari setiap perlakuan disajikan pada Gambar 6. Hasil analisis ragam menunjukkan bahwa perlakuan tidak memeberikan pengaruh yang berbeda nyata terhadap tingkat kelangsungan hidup benih rajungan $(P$. pelagicus $)(\mathrm{P}=0,622>0,05)$.

\section{Kualitas Air}

Pengukuran kualitas air selama penelitian meliputi suhu, salinitas, $\mathrm{pH}$, oksigen terlarut dan amoniak, disajikan pada Tabel 4.

Tabel 4. Hasil Pengukuran Kualitas Air selama Pemeliharaan.

\begin{tabular}{llcl}
\hline No & \multicolumn{1}{c}{ Parameter } & Nilai & \multicolumn{1}{c}{ Optimal } \\
\hline 1. & Suhu $\left({ }^{\circ} \mathrm{C}\right)$ & $25-27^{\circ} \mathrm{C}$ & $27-32^{\circ} \mathrm{C}($ Nugraheni $d k k ., 2015)$. \\
2. & Salinitas $(\mathrm{ppt})$ & $25-28 \mathrm{ppt}$ & $25 \mathrm{ppt}($ Hastuti $d k k ., 2015)$ \\
3. & $\mathrm{pH}$ & $7-8$ & $7-9(\mathrm{Ihsan} d k k ., 2019)$. \\
4. & DO $(\mathrm{mg} / \mathrm{L})$ & $4,5-5,7$ & $4,34-5,94 \mathrm{mg} / \mathrm{l}(\mathrm{Ihsan} d k k ., 2019)$ \\
5. & Amoniak $(\mathrm{mg} / \mathrm{L})$ & $0,031-0,037$ & $0,004-0,019 \mathrm{ppm}$ (Yusneri $d k k ., 2020)$ \\
\hline
\end{tabular}




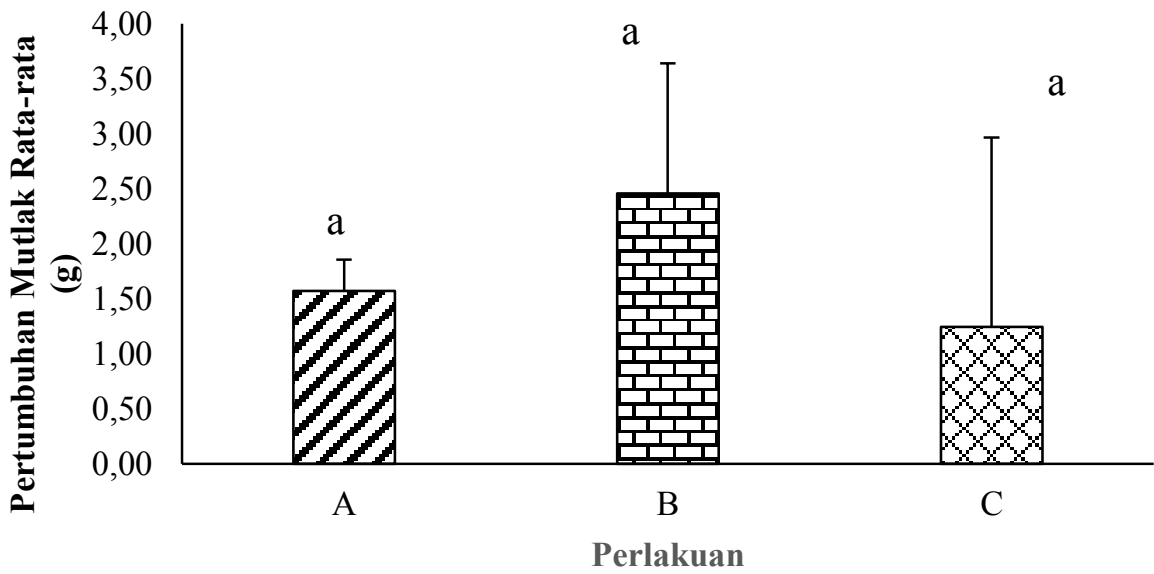

Gambar 1. Pertumbuhan Mutlak Rata-rata Juvenil Rajungan (P. pelagicus) selama Penelitian, Pakan A (6\% MI $+0 \% \mathrm{MJ})$; Pakan B (3\% MI + 3\% MJ); dan Pakan C (2\% MI + 4\% MJ). a superscript yang sama menunjukkan tidak ada perbedaan signifikan pada taraf $\alpha=0,05$.

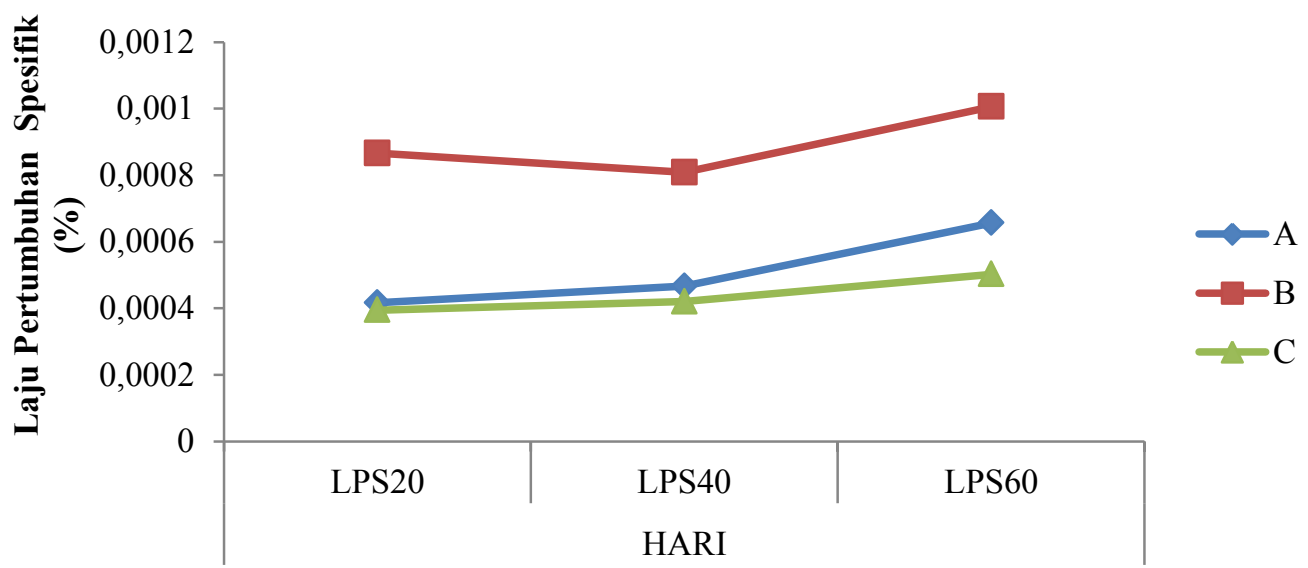

Gambar 2. Laju Pertumbuhan Spesifik Juvenil Rajungan (P. pelagicus) selama Penelitian, Pakan A (6\% MI + 0\%MJ); Pakan B (3\% MI + 3\% MJ); dan Pakan C (2\% MI + 4\% MJ).

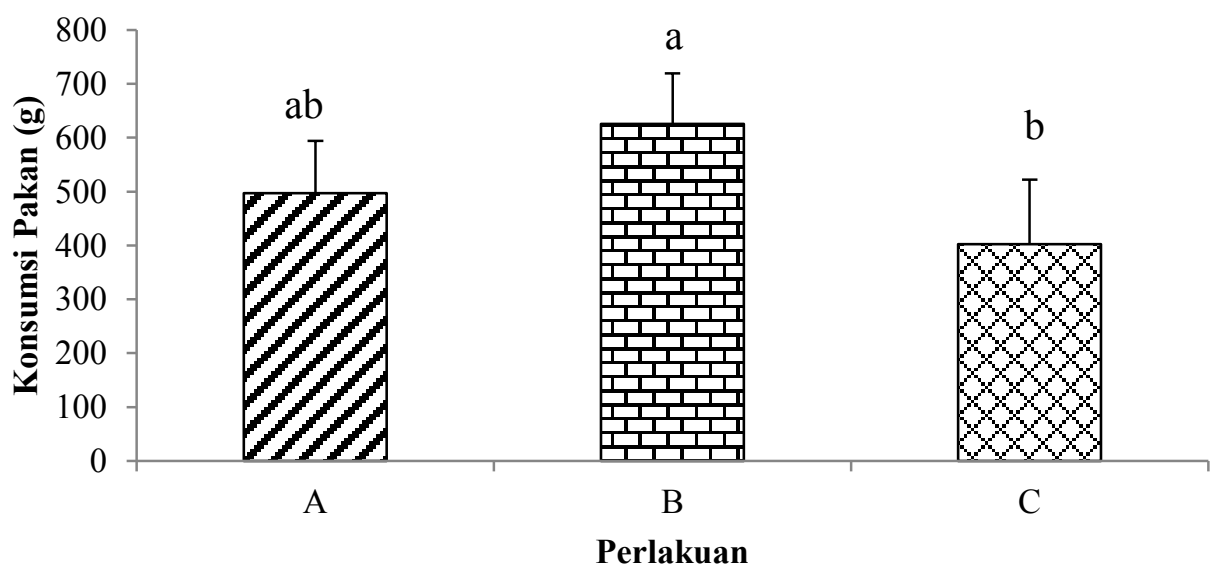

Gambar 3. Konsumsi Pakan Juvenil Rajungan (P. pelagicus) selama Penelitian, Pakan A (6\% MI $+0 \% \mathrm{MJ})$; Pakan B (3\% MI $+3 \%$ MJ); dan Pakan C (2\% MI $+4 \%$ MJ). ${ }^{\mathrm{a}, \mathrm{b}}$ superscript yang berbeda menunjukkan perbedaan signifikan pada taraf $\alpha=0,05$. 


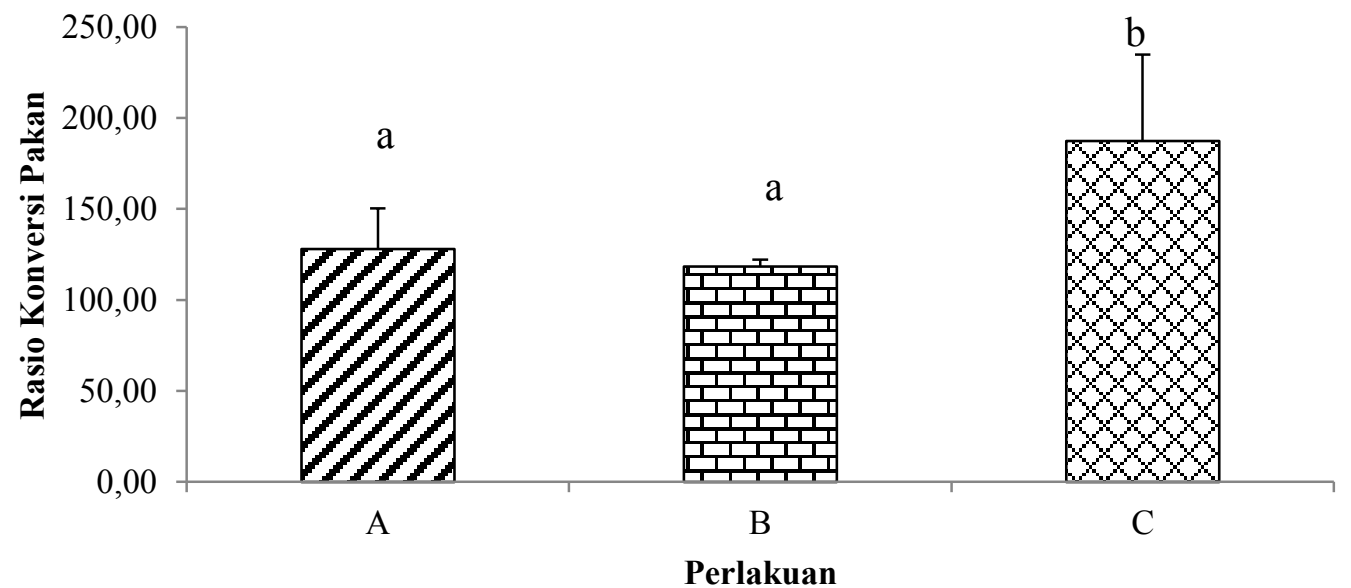

Gambar 4. Rasio Konversi Pakan Juvenil Rajungan (P. pelagicus) selama Penelitian, Pakan A (6\% MI + $0 \% \mathrm{MJ})$; Pakan B (3\% MI + 3\% MJ) ; dan Pakan C (2\% MI + 4\% MJ). ${ }^{\mathrm{a}, \mathrm{b}}$ superscript yang berbeda menunjukkan perbedaan signifikan pada taraf $\alpha=0,05$.

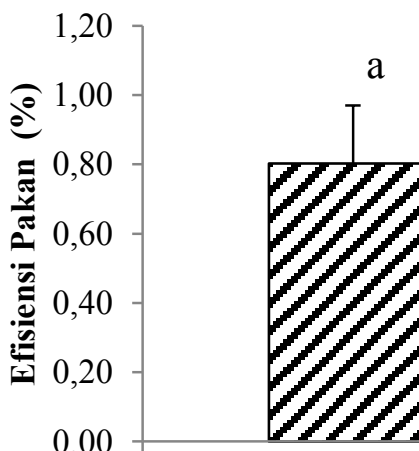

A

a

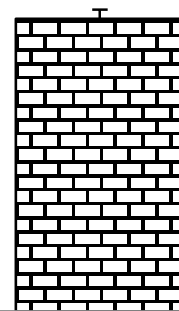

B b

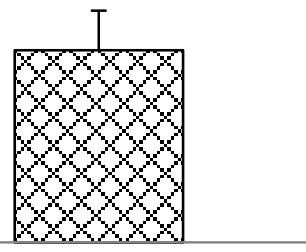

$\mathrm{C}$

\section{Perlakuan}

Gambar 5. Efisiensi Pakan Juvenil Rajungan (P. pelagicus) selama Penelitian, Pakan A (6\% MI $+0 \% \mathrm{MJ})$; Pakan B (3\% MI + 3\% MJ); dan Pakan C (2\% MI $+4 \% \mathrm{MJ})$. ${ }^{\mathrm{a}, \mathrm{b}}$ superscript yang berbeda menunjukkan perbedaan signifikan pada taraf $\alpha=0,05$.

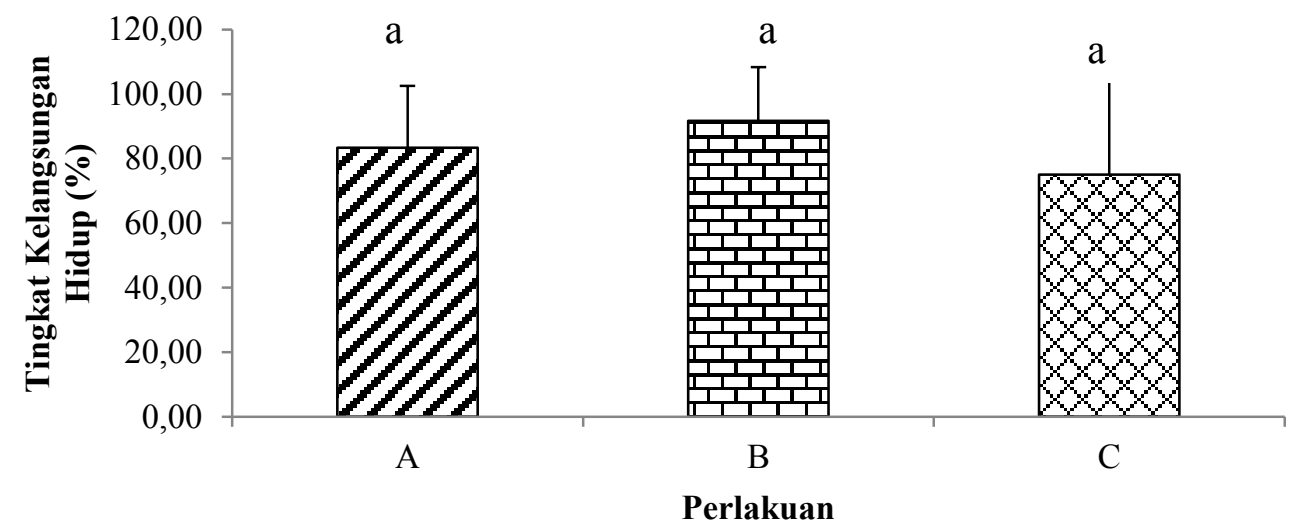

Gambar 6.Tingkat Kelangsungan Hidup Juvenil Rajungan(P. pelagicus) selama Penelitian: Pakan A (6\% MI + 0\%MJ); Pakan B (3\% MI + 3\% MJ); dan Pakan C (2\% MI + 4\% MJ). ${ }^{\text {a }}$ superscript yang sama menunjukkan tidak ada perbedaan signifikan pada taraf $\alpha=0,05$. 


\section{PEMBAHASAN}

Secara statistik pertumbuhan mutlak rata-rata dan laju pertumbuhan spesifik juvenil rajungan yang diberi pakan perlakuan tidak memberikan hasil yang berbeda nyata. Namun, kecenderungan pertumbuhan mutlak rata-rata dan laju pertumbuhan spesifik juvenil rajungan yang diberi pakan yang mengandung sumber lemak hewani dan lemak nabati yang seimbang (3\% MI : 3\% MJ) lebih tinggi dibandingkan perlakuan A (6\% MI : $0 \%$ MJ) dan Perlakuan B (2\% MI : $4 \% \mathrm{MJ})$. Hal ini diduga disebabkan juvenil rajungan selain membutuhkan asam lemak omega-3 Eicosapentaenoic acid(EPA) dan Docosahexaenoic acid (DHA) juga membutuhkan asam lemak omega-6 (Asam linoleat) dan asam lemak omega-9 (Asam linolenat) dalam porsi yang sama untuk menunjang pertumbuhan. Menurut Supriyadi et al. (2002), jumlah perbandingan antara EPA dan DHA pada pakan merupakan suatu ukuran yang sangat penting dalam menentukan pertumbuhan dan kelangsungan hidup larva Scylla serrata. Merupakan berbagai jenis sumber asam lemak (EPA dan DHA) yang sangat dibutuhkan oleh tubuh. Suarni dan Widowati (2010), mengatakan bahwa, kualitas minyak jagung cukup tinggi dan seimbang terutama asam oleat dan linoleat. Hal ini sejalan dengan pernyataan Alfin dkk. (2017) kandungan yang terdapat pada minyak jagung berupa asam oleat $20 \%-50 \%$, asam linoleat $35 \%-60 \%$, fosfolipid $2 \%$ dan bahan-bahan tak tersambunkan 2\% (tokoferol, sitosferol dan lilin). Menurut Rachmatikawati (2010) dalam Priyadi (2012), kandungan asam lemak yang terdapat pada jagung seperti asam lemak jenuh (palmitat dan stearat)serta asam lemak tidak jenuh, yaitu oleat (Omega 9) dan linoleat (Omega 6). Menurut Haikal dkk. (2017), dikarenakan tingginya penggunaan dosis minyak nabati (minyak kelapa tradisonal) sehingga menyebabkan rendahnya pertumbuhan lobster. Untuk metabolisme energi serta untuk menjaga struktur membran sel larva selama pemeliharaan.

Hasil penelitian menunjukkan pertumbuhan mutlak rata-rata juvenil rajungan yang didapatkan berkisar 1,25 $\pm 1,72$ g$2,46 \pm 1,18$ g. perlakuan yang cenderung lebih tinggi diperoleh pada perlakuan B yaitu sebesar $(2,46 \pm 1,18 \mathrm{~g})$, dan nilai terendah diperoleh pada perlakuan C sebesar $(1,25 \pm 1,72 \mathrm{~g})$. Hasil penelitian ini lebih rendah dibandingkan hasil penelitian Alfin dkk. (2017), tentang subtitusi minyak ikan dengan minyak jagung dalam pakan terhadap pertumbuhan dan kelangsungan hidup lobster laut yang menghasilkan pertumbuhan mutlak rata-rata lobster laut dengan lama pemeliharaan 4 bulan berkisar antara $3,24 \pm 0,24 \mathrm{~g}-4,12 \pm 0,77 \mathrm{~g}$. Hal ini diduga disebabkan perbedaan waktu pemeliharaan dapat mempengaruhi pertumbuhan organisme.

Hasil penelitian menunjukkan pertumbuhan mutlak rata-rata juvenil rajungan yang didapatkan berkisar 1,25 $\pm 1,72$ g$2,46 \pm 1,18$ g. perlakuan yang cenderung lebih tinggi diperoleh pada perlakuan B yaitu sebesar $(2,46 \pm 1,18 \mathrm{~g})$, dan nilai terendah diperoleh pada perlakuan $\mathrm{C}$ sebesar $(1,25 \pm 1,72 \mathrm{~g})$. Hasil penelitian ini lebih rendah dibandingkan hasil penelitian Alfin dkk. (2017), tentang subtitusi minyak ikan dengan minyak jagung dalam pakan terhadap pertumbuhan dan kelangsungan hidup lobster laut yang menghasilkan pertumbuhan mutlak rata-rata lobster laut dengan lama pemeliharaan 4 bulan berkisar antara $3,24 \pm 0,24 \mathrm{~g}-4,12 \pm 0,77 \mathrm{~g}$. Hal ini diduga disebabkan perbedaan waktu pemeliharaan dapat mempengaruhi pertumbuhan organisme.

. Pakan merupakan salah satu faktor penunjang petumbuhan juvenil rajungan. Berdasarkan hasil penelitian menunjukkan juvenil rajungan yang dipelihara selama 60 hari memberikan pengaruh yang berbeda nyata terhadap konsumsi pakan juvenil rajungan. Pemberian pakan perlakuan B (3\% MI; 3\% MJ) menunjukkan nilai konsumsi pakan terbaik yaitu sebesar $625,68 \pm 93,91 \mathrm{~g}$. Tingginya nilai konsumsi pakan pada perlakuan ini diduga pakan yang diberikan disukai oleh juvenil rajungan karena memiliki aroma bau khas yang dihasilkan dari minyak jagung mampu menambah nafsu makan juvenil rajungan serta mengandung asam lemak yang dibutuhkan oleh tubuh juvenil rajungan. Sejalan dengan nilai rasio konversi pakan dan efisiensi pakan yang terbaik diperoleh pada perlakuan B. Hal ini sesuai dengan pernyataan Saltin dkk. (2016) bahwa, tingginya nilai konsumsi pakan disebabkan pakan yang diberikan memliki aroma/bau yang khas sehingga meningkatkan ketertarikan post larva udang windu. 
Hasil analisis ragam menunjukkan perlakuan memberikan pengaruh yang berbeda nyata terhadap rasio konversi pakan dan efisiensi pakan juvenil rajungan. Nilai rasio konversi pakan juvenil rajungan terendah diperoleh pada perlakuan B yaitu sebesar 118,43 , sejalan dengan tingginya nilai efisiensi pakan pada perlakuan B yaitu sebesar $0,85 \%$. pada minyak ikan dapat menunjang penyerapan kebutuhan nutrisi yang baik pada organisme sehingga konversi pakan rendah dan evesiensi pakan yang tinggi, yang mana keduanya menunjukkan keseimbangan. Hai ini didukung oleh penyataan Suarni dan Widowati (2005), mengatakan bahwa, kualitas minyak jagung cukup tinggi dan seimbang terutama asam oleat dan linoleat. Meskipun secara statistik tidak memberikan pengaruh terhadap pertumbuhan mutlak rata-rata akan tetapi memberikan nilai tertinggi pada perlakuan B dibandingkan dengan perlakuan A dan C. Semakin rendah nilai rasio konversi pakanmaka semakin efisien pula penggunaan pakannya karena semakin sedikit pula jumlah pakan yang diberikan untuk menghasilkan bobot tertentu. Hal ini didukung oleh pernyataan Agustono dkk. (2009) ; Alfin, (2017) bahwa semakin rendah nilai rasio konversi pakan semakin baik pula pakan tersebut, karena semakin sedikit jumlah pakan yang dibutuhkan untuk menghasilkan berat tertentu. Menurut Alfin (2017), nilai rasio konversi pakan berbanding terbalik dengan pertambahan bobot, sehingga semakin rendah nilainya maka semakin efisien lobster dalam memanfaatkan pakan yang dikonsumsi untuk pertumbuhan.Menurut Alit (2013), nilai efisiensi pakan dapat menunjukkan kemampuan ikan untuk memanfaatkan pakan yang dikonsumsi. Kemudian Handajani (2011), menyatakan bahwa tingkat efisiensi pemanfaatan pakan terbaik dicapai pada nilai perhitungan konversi pakan terendah, dimana pada perlakuan tersebut kondisi kualitas pakan lebih baik dari perlakuan lain. Menurut Lestari et al. (2013), keefisienan penggunaan pakan dilihat dari nilai pakan yang dapat merubah menjadi pertambahan berat.

Tingkat kelangsungan hidup pada penelitian ini sangat penting karena untuk mengetahui tingkat keberhasilan dalam pemeliharaan hewan uji. Berdasarkan hasil penelitian yang telah dilakukan selama 60 hari, tingkat kelangsungan hidup dari ketiga perlakuan menunjukan tidak memberikan pengaruh yang berbeda nyata. Namun, tingkat kelangsungan hidup tertinggi didapatkan pada perlakuan B $(91,67 \%)$ dan A $(83,33 \%)$ sedangkan terendah didapatkan pada perlakuan C (75,00\%). Tingginya persentase tingkat kelangsungan hidup yang diperoleh dalam penelitian ini diduga sistem resirkulasi pada pemeliharan benih rajungan mampu menjaga kualitas air sehingga tingkat mortalitas rendah dan pemberian pakan yang sesuai serta tidak berlebihan dapat menjaga kestabilan kualitas air tetap sesuai pada kisaran optimum untuk pertumbuhan dan kelangsungan hidup benih rajungan. Hal ini didukung oleh pernyataan Qamariah dkk. (2016) bahwa, Tingginya kelangsungan hidup disebabkan oleh ketersediaan pakan yang cukup dan sistem resirkulasi tetap menunjang kestabilan kualitas air.Menurut Yustianti dkk.(2013) bahwa, faktor yang paling mempengaruhi kelangsungan hidup yaitu pengelolaan dalam pemberian pakan dan pengelolaan kualitas air yang baik pada media pemeliharaan. Menurut Suharyanto (2012), faktor utama keberhasilan budidaya adalah pengelolaan kualitas air sesuai dengan habitat aslinya dapat menunjang kelangsungan hidup rajungan.

Parameter kualitas air merupakan faktor penting yang mempengaruhi pertumbuhan dan kelangsungan hidup benih rajungan. Parameter yang diukur selama penelitian yaitu salinitas, suhu, $\mathrm{pH}$, Amoniak dan DO. Hasil pengukuran kualitas air yang didapatkan selama penelitian diantaranya : suhu berkisar $25-27^{\circ} \mathrm{C}$, salinitas berkisar $25-28 \mathrm{ppt}$, $\mathrm{pH} 7-8$, oksigen terlarut berkisar antara 4,5-5,7 $\mathrm{mg} / \mathrm{L}$, dan amonia berkisar antara 0,031-0,037 $\mathrm{mg} / \mathrm{L}$. Kisaran ini masih berada pada kisaran normal untuk menunjang pertumbuhan dan kelangsungan hidup benih rajungan. Hal ini sesuai dengan pernyataan Ihsan dkk. (2019) Menyatakan bahwa, salinitas 28-31 ppt, pH 79, dan Oksigen terlarut 4,34-5,94 mg/1 masih dalam kisaran optimal untuk pertumbuhan dan kelangsungan hidup larva rajungan. Menurut Menurut Jumaisa dkk., (2016) menyatakan bahwa suhu berkisar $26-29^{\circ} \mathrm{C}$ masih berada dalam kisaran yang dapat ditolerir oleh oleh kepiting rajungan, Menurut Hastuti dkk. 2015; Jumaisa dkk. (2016) menyatakan bahwa salinitas terbaik bagi pertumbuhan dan sintasan kepiting adalah 25 ppt. Menurut Riady dkk. 
(2016) menyatakan bahwa, Kualitas air yang sesuai bagi kehidupan organisme akuatik merupakan faktor penting karena berpengaruh terhadap reproduksi, pertumbuhan dan kelangsungan hidup organisme perairan.

\section{KESIMPULAN}

Subtitusi minyak ikan dan minyak jagung memberikan pengaruh yang sama terhadap pertumbuhan mutlak, laju pertumbuhan spesifik, dan kelangsungan hidup, tetapi memberikan pengaruh yang berbeda terhadap konsumsi pakan, rasio konversi pakan, efisiensi pakan, retensi protein, dan retensi lemak juvenil rajungan.

Pertumbuhan dan efisiensi pakan terbaik didapatkan pada juvenil rajungan yang diberi pakan buatan yang mengandung 3\% minyak ikan dan 3\% minyak jagung dalam pakan.

\section{REFERENSI}

Agustono, Hadi. M, Cahyoko, Y. 2009. Pemberian tepung limbah udang yang difermentasi dalam ransum pakan buatan terhadap laju pertumbuhan, rasio konversi pakan dan kelangsungan hidup benih ikan nila.Fakultas Perikanan dan Kelautan Universitas Airlangga.Jurnal Ilmiah Perikanan dan Kelautan, 157162.

Alfin., Kurnia, A. dan Hamzah, M. 2017. Substitusi Minyak Ikan dengan Minyak Jagung dalam Pakan Terhadap Pertumbuhan dan Kelangsungan Hidup Lobster Air Laut (Panulirus sp.).Media Akuatika, 2(1): 270-278

Alit, A.A. 2013.Pendederan Benih Ikan Bandeng (Chanos chanos Forskall) dengan Perlakuan Dosis Pakan Berbeda di Bak Terkontrol.Prosiding Seminar Nasional Tahunan X Hasil Penelitian Perikanan dan Kelautan Jilid I. Universitas Gajah Mada. Yogyakarta, 16.

Haikal, M., Kurnia, A. dan Muskita, W.H. 2017.Pengaruh Kombinasi Tepung Keong Bakau (Telescopium telescopium) dan Minyak Kelapa Tradisional dalam Pakan Buatan terhadap Pertumbuhan Lobster Mutiara (Panulirus ornatus). Media Akuatika, 2(3): 418-425
Handajani, H dan Widodo, W. 2011. Nutrisi Ikan. UMM Press. Malang. 267 hal.

Handajani, H. 2011. Optimalisasi Substitusi Tepung Azolla Terfermentasi pada Pakan Ikan untuk Meningkatkan Produktivitas Ikan Nila Gift. Jurnal Teknik Industri, 12(2) : 177-181.

Hastuti, P.Y., Affandi, R., Safrina, D. F., Faturrohman, K., dan Nurussalam, W. 2015.Salinitas optimum untuk pertumbuhan benih kepiting bakau Scylla serrata dalam sistem resirkulasi.Jurnal Akuakultur Indo- nesia 14 (1), 50-57.

Ihsan, Asbar, dan Asmidar. 2019. Kajian Kesesuaian Lingkungan Perairan untuk Budidaya Rajungan dalam Keramba Jaring Apung Ditenggelamkan di Perairan Kabupaten Pangkep Provinsi Sulawesi Selatan.Prosiding Simposium Nasional Kelautan dan Perikanan VI. Universitas Hasanuddin, Makassar, 21 Juni 2019. 249-258 hal.

Jumaisa, Idris. M., dan Astuti. O. 2016. Pegaruh Salinitas Berbeda terhadap Pertumbuhan dan Kelangsungan Hidup Juvenil Rajungan (Portunus pelagicus). Jurnal Media Akuatika, Vol.1(2): 94-103 hal.

Kurnia, A., Muskita, W.H., Yusnaini., Hamzah, M. dan Astuti, O. 2018. an Evaluation of Traditional Coconut Oil as an Alternative Lipid Ingredient in the Diet on the Growth and Carcass Composition of Spiny Lobster, Panulirus Ornatus. IOSR Journal of Agriculture and Veterinary Science (IOSR-JAVS),.Volume 11, Issue 9 Ver.I : PP 52-57.

Lestari. S., Fuji., Salnida Y, dan Zaenal, A. 2013. Pengaruh Formulasi Pakan Berbahan Baku Tepung Ikan, Tepung Jagung, Dedak Halus dan Ampas Tahu Terhadap Pertumbuhan Ikan Nila (Oreochromis niloticus). Jurnal Kelautan, 6 (1):1-8.

Mardjono, M., L. Ruliaty., R. Prasetyo., dan Sugen. 2002. Pemeliharaan Larva Rajungan (Portunus pelagicus) Skala Massal. Balai Besar Pengembangan Budidaya Air Payau Jepara 3 (1): 1-9.

Nugraheni, D. I., Fahrudin, A dan Yonvitner. 2015. Variasi Ukuran Lebar Karapaks dan Kelimpahan Rajungan (Portunus 
pelagicus linnaeus) di Perairan Kabupaten Pati. Jurnal Ilmu dan Teknologi Kelautan Tropis. 7(2): 493510 .

Priyadi, S.M. 2012. Laporan tugas akhir analisa stabilitas homogenesasi saladdressing dari minyak jagung dan jeruk nipis dengan penambahan kuning telur sebagai emulsifer. Program Diploma Fakultas Teknik. Universitas Diponegoro. Semarang. 40 hal.

Qamariah, N., Muskita, W.H., Astuti, O dan Kurnia, A. 2016. Pengaruh Pemberian Keong Bakau (Telescopium telescopium) dan Cumi-cumi (Loligo sp.) terhadap Pertumbuhan dan Kelangsungan Hidup Rajungan (Portunus pelagicus). Jurnal Media Akuatika. 1 (2):84-93.

Riady, A., Muskita, W.H dan Hamzah, M. 2016.Subtitusi Minyak Ikan dengan Minyak Kelapa Tradisional dalam Pakan terhadap Pertumbuhan dan Kelangsungan Hidup Lobster Air Laut (Panulirus sp.).Jurnal Media Akuatika. 1(2):111-119.

Saltin, A., Idris, M. dan Kurnia, A. 2016. Pengaruh Penambahan Minyak Ikan Salmon dalam Pakan Terhadap Pertumbuhan dan Sintasan Post Larva Udang Windu (Penaeus monodon).Media Akuatika, 1(4): 234242

Soim. 1996. Pembesaran kepiting. Penebar Swadaya. Jakarta. 62 pp.

Suarni dan Widowati, S. 2010. Struktur, Komposisi dan Nutrisi Jagung. Balai Penelitian Tanaman Serealia. Maros.15 hal.

Suharyanto dan S. Tahe. 2005. Pengaruh padat tebar berbeda terhadap pertumbuhan dan sintasan kepiting rajungan (Portunus pelagicus) di tambak. Jurnal Riset Akuakultur. 2(1):19-25

Suharyanto, S. Tahe., Y. Aryani., dan M. Mangampa. 2006. Pembesaran kepiting rajungan (Portunus pelagicus) di tambak dengan penambahan selter yang berbeda. Laporan Penelitian. Balai Riset Perikanan Budidaya Air Payau, Maros. 15 hal.

Suharyanto. 2012. Pengaruh Pemberian Kombinasi Pakan Ikan Rucah dan Pakan Buatan (Pelet) terhadap Pertumbuhan dan Laju Sintasan Rajungan (Portunus pelagicus). Biosfera, 29(2): 93-101.

Sunarto dan Sabariah. 2008. Pengaruh Sumber Asam Lemak Pakan Berbeda terhadap Kinerja Pertumbuhan Ikan Botia (Botia macrachantus Bleeker). Jurnal Akuakultur Indonesia, Pontianak 7(2): 199-204.

Sunarto. 2012. Karakteristik Bioekologi Rajungan (Portunus pelagicus ) di Perairan Laut Kabupaten Brebes. Sekolah Pascasarjana Institut Pertanian Bogor. Bogor. 1-210.

Suprayudi MA, T Takeuchi, K Hamasaki, \& J Hirokawa. 2002 The effect of n-3 HUFA content in rotifer on the development and survival of mud crab, Scylla serrata, larvae. Japan Aquaculture Society, 50(2):205-212P.

Yustianti., Ibrahim, M. N., dan Ruslaini. 2013. Pertumbuhan dan Sintasan Larva Udang Vaname (Lithopenaeus vannamei) melalui SubstitusiTepung Ikan dengan Tepung Usus Ayam. Jurnal Mina Laut Indonesia. 1(1):93-103. 